Article

\title{
Transition-Metal-Free Highly Efficient Aerobic Oxidation of Sulfides to Sulfoxides under Mild Conditions
}

\author{
Hua Zhang ${ }^{1, *}$, Chunyu Chen ${ }^{1}$, Renhua Liu ${ }^{2}$, Qiang Xu ${ }^{1}$ and Weiqie Zhao ${ }^{1}$
}

1 State Key Laboratory of Fine Chemicals, School of Chemical Engineering, Dalian University of Technology, No.158-139, Zhongshan Road, Dalian 116012, China;

E-Mails: chenchunyu321@yahoo.cn (C.Y.C.); xuqianguser@163.com (Q.X.).;

zyzhao@chem.dlut.edu.cn (W.Q.Z.)

2 School of Pharmacy, East China University of Science and Technology, Shanghai 200237, China;

E-Mail: liurh@ecust.edu.cn (R.L.)

* Author to whom correspondence should be addressed; E-Mail: huazhang@chem.dlut.edu.cn.

Received: 30 November 2009; in revised form: 17 December 2009 / Accepted: 23 December 2009 / Published: 28 December 2009

\begin{abstract}
A highly efficient transition-metal-free catalytic system $\mathrm{Br}_{2} / \mathrm{NaNO}_{2} / \mathrm{H}_{2} \mathrm{O}$ has been developed for a robust and economic acid-free aerobic oxidation of sulfides. It is noteworthy that the sulfide function reacts under mild conditions without over-oxidation to sulfone. The role of $\mathrm{NaNO}_{2}$ as an efficient $\mathrm{NO}$ equivalent for the activation of molecular oxygen was identified. Under the optimal conditions, a broad range of sulfide substrates were converted into their corresponding sulfoxides in high yields by molecular oxygen. The present catalytic system utilizes cheap and readily available agents as the catalysts, exhibits high selectivity for sulfoxide products and releases only innocuous water as the by-products.
\end{abstract}

Keywords: aerobic oxidation; sulfids; $\mathrm{Br}_{2} ; \mathrm{NaNO}_{2} ;$ molecular oxygen

\section{Introduction}

The oxidation of sulfides into the corresponding sulfoxides is one of the most important functional group transformations in organic synthesis [1]. Sulfoxides as a class of important compounds are generally used as synthetic intermediates for the construction of various chemically and biologically 
significant molecules [2-3], as well as for the synthesis of drugs and natural products [3-5], Therefore, many efficient methods have been developed for the oxidation of sulfides to sulfoxides. However, it is difficult to control the results while the sulfoxides could be further oxidized to sulfones. A large number of methods have been developed to overcome this drawback; however, most of these reactions require a stoichiometric amount of oxidant, resulting in undesirable waste [6-8]. Hydrogen peroxide and molecular oxygen has recently been utilized as an attractive and environmentally benign oxidant for the oxidation of sulfides, because they are inexpensive, easy to handle, safely stored, and produce only water as a side-product [9-12]. Hydrogen peroxide is usually applied in catalytic sulfide oxidations system since it is an environmentally benign oxidant [13-18]. However, selective oxidation by molecular oxygen is even more attractive because of its obvious economical and environmental advantages [19-22].

Recently, the use of molecular oxygen as terminal oxidant has received great attention for both economic and environmental benefits, and many highly efficient systems have been developed for catalytic aerobic sulfide oxidation using rhenium [23], palladium [24], ruthenium [25], copper [26,27] manganese [26], iron [27-29], cobalt [30] and gold-based catalysts [31]. However, the metal catalysts can be expensive and may hinder the purification of products, and cause some environment problems. Only a few catalyst systems, for example, small amounts of cheap metal salts, provide an efficient catalyst for aerobic oxidation of sulfides under mild conditions. Therefore, the development of an efficient nonmetallic catalyst for the aerobic oxidation of sulfides under mild conditions has long been desired. Our research was inspired by the mechanism of selective catalysis of thioether oxidations with dioxygen by Bosch et al. [32] who reported the facile and selective oxidation of various aliphatic and aromatic sulfides by the combination of $\mathrm{NO}_{2}$ and dioxygen at room temperature and below. The catalysis of thioether autoxidation was also effected by small amounts of other nitrogen oxides, such as nitric oxide and nitrosonium salts. $\mathrm{NaNO}_{2}$ as an alternative $\mathrm{NO}$ source for their property were identified as an efficient $\mathrm{NO}$ equivalent for the activation of molecular oxygen $[33,34]$. In this context, a process for the highly efficient aerobic oxidation of a wide range of sulfides utilizing a DBDMH/ $\mathrm{NaNO}_{2}$ and $\mathrm{HBr} / \mathrm{t}-\mathrm{BuONO}$ catalyst system that was free from any transition-metal cocatalysts has been disclosed by our research group [35,36]. On the other hand, the halogens and their derivatives are considered environmentally unfriendly, despite their advantages such as low price, easy handling, commercial availability, and relatively high stability. The biggest disadvantage of the utilization of molecular bromine in the oxidation of sulfides is the formation of byproducts such as sulfonic or sulfinic acids and bromosubstituted sulfides or sulfones [37]. If $\mathrm{Br}_{2}$ was only used in catalytic amounts but not in stoichiometric amount, the transformation of sulfides into the corresponding sulfoxides could be more attractive and effective oxidation procedure using molecular oxygen. A novel metal-free catalytic system $\mathrm{Br}_{2} / \mathrm{NaNO}_{2} / \mathrm{H}_{2} \mathrm{O}$ for the highly selective oxidation of a variety of sulfides using molecular oxygen as the terminal oxidant in a small amount of water at ambient temperature (Scheme 1) is reported in this paper. 
Scheme 1. Oxidation of sulfides to the corresponding sulfoxides.

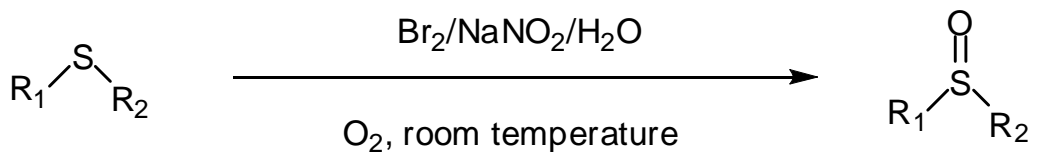

\section{Results and Discussion}

Initial investigation of aerobic oxidation was carried out using methyl phenyl sulfide as a substrate with $3 \mathrm{~mol} \%$ of $\mathrm{Br}_{2}$ and oxygen under $25^{\circ} \mathrm{C}$ for $1 \mathrm{~h}$. The preliminary result ( $21 \%$ conversion) clearly indicated the role of $\mathrm{Br}_{2}$ as an active catalyst. We sought to find a co-catalyst to bridge the gap between $\mathrm{O}_{2}$ activation and $\mathrm{HBr}$ reoxidation. The ready availability and unique redox property of $\mathrm{NaNO}_{2}$ as a source of $\mathrm{NO}$ under acidic conditions attracted our attention. Although $\mathrm{NaNO}_{2}$ alone showed little activity ( $10 \%$ conversion), when $3 \mathrm{~mol} \%$ of $\mathrm{Br}_{2}$ and $5 \mathrm{~mol} \%$ of $\mathrm{NaNO}_{2}$ were both employed in aerobic oxidation, a highly efficient catalyst system emerged. The keys to the newly developed oxidation process are the discovery of molecular oxygen being able to oxidize $\mathrm{HBr}$ to $\mathrm{Br}_{2}$ in situ with $\mathrm{NaNO}_{2}$ as the catalyst and its suitability in an aqueous environment (Table 1).

Table 1. The catalysts effect on the reaction. ${ }^{a}$

\begin{tabular}{cccc}
\hline Entry & $\mathbf{N a N O}_{\mathbf{2}}(\mathbf{m o l ~ \% )}$ & $\mathbf{B r}_{\mathbf{2}}(\mathbf{m o l} \%)^{\mathbf{b}}$ & Conversion (\%) $^{\mathbf{c}}$ \\
\hline 1 & 0 & 3 & 21 \\
2 & 5 & 0 & 10 \\
3 & 5 & 3 & 100 \\
\hline
\end{tabular}

${ }^{\mathrm{a}}$ Reaction conditions: methyl phenyl sulfide (MPS) $(10 \mathrm{mmol}), \mathrm{O}_{2}(80 \mathrm{~mL} / \mathrm{min}), 25{ }^{\circ} \mathrm{C}$, $\mathrm{H}_{2} \mathrm{O}(1.5 \mathrm{~mL}) ;{ }^{\mathrm{b}} \mathrm{Br}_{2}(0.3 \mathrm{mmol}, 0.015 \mathrm{~mL}), \mathrm{NaNO}_{2}(0.5 \mathrm{mmol}, 0.0345 \mathrm{~g}) ;{ }^{\mathrm{c}}$ Conversions were determined by GC and counted with area normalization.

\subsection{Aerobic oxidation of sulfides to sulfoxides}

Ten mmol substrates of analogues of methyl aryl sulfides were reacted with 5 mol \% of $\mathrm{NaNO}_{2}$ in the presence of $3-5 \mathrm{~mol} \% \mathrm{Br}_{2}, 1.5 \mathrm{~mL}$ of water and oxygen $(80 \mathrm{~mL} / \mathrm{min})$ in $\mathrm{CH}_{3} \mathrm{CN}$ under $25{ }^{\circ} \mathrm{C}$ in $1 \mathrm{~h}$. The reactions were took place efficiently (Table 2 ).

Table 2. Catalytic aerobic oxidation of sulfide in a small amount of water. ${ }^{\text {a }}$

\begin{tabular}{|c|c|c|c|c|c|c|}
\hline Entry & Substrate & Product & $\begin{array}{c}\text { Time } \\
\text { (h) }\end{array}$ & $\begin{array}{c}\mathrm{Br}_{2} \\
(\mathrm{~mol} \%)\end{array}$ & $\begin{array}{c}\text { Conversion } \\
(\%)^{\mathbf{b}} \\
\end{array}$ & $\begin{array}{l}\text { Yield } \\
(\%)^{c}\end{array}$ \\
\hline 1 & & & 1 & 3 & 100 & 96 \\
\hline 2 & & & 1 & 3 & 100 & 92 \\
\hline
\end{tabular}


Table 2. Cont.

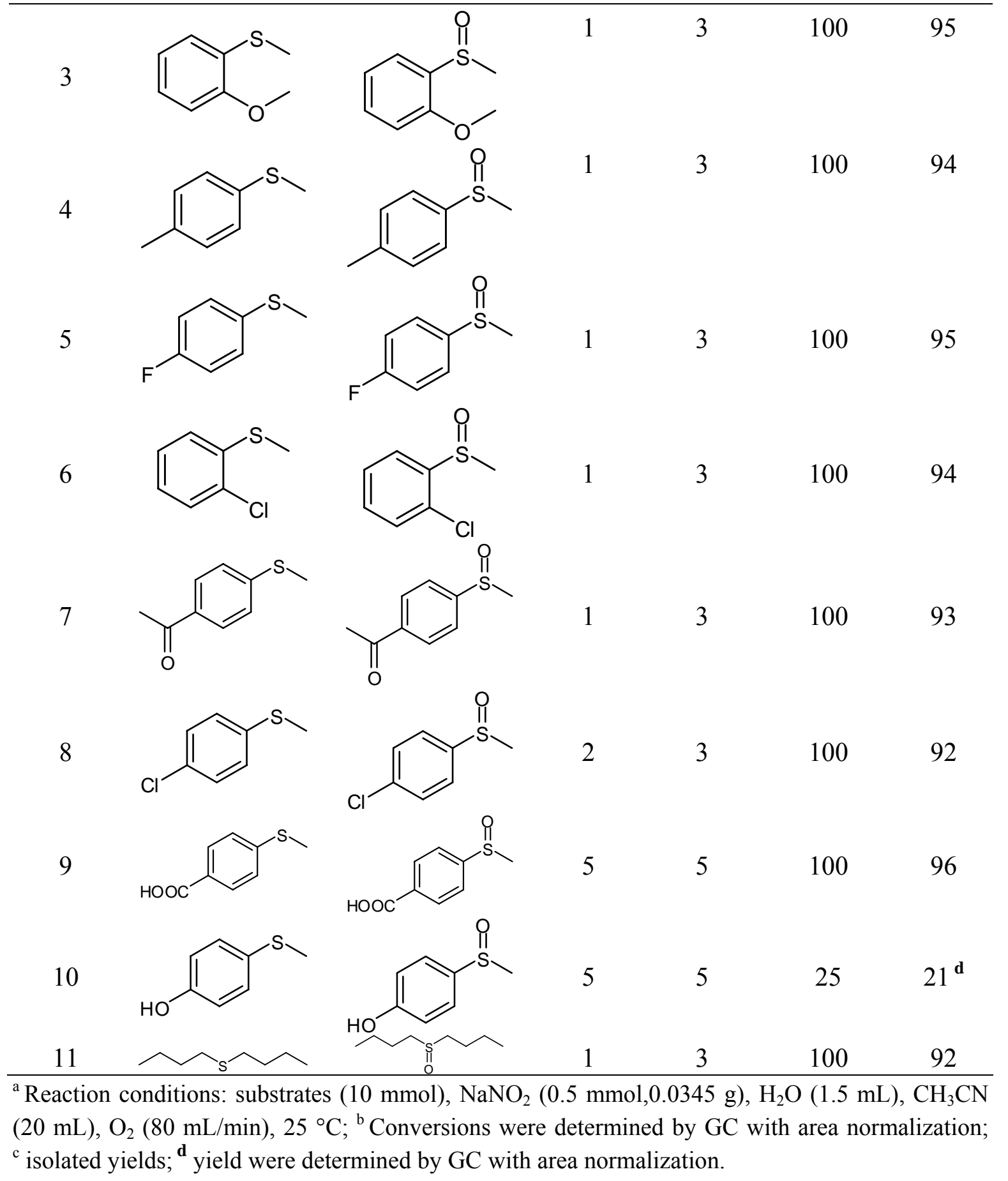

As shown in Table 2, most of methyl aryl sulfides including electron-rich and nucleophilic-rich aromatic compounds were converted into their corresponding sulfoxides in high isolated yields within $1 \mathrm{~h}$ (entries 1-7). 4-Chlorophenyl methyl sulfide and 4-(methylthio)benzoic acid showed relatively low activities in the oxidation. To address this, we prolonged the reaction time to $2 \mathrm{~h}$, 4-Chlorophenyl methyl sulfide was thus converted into 4-chlorophenyl methyl sulfoxide with 100\% conversion in high isolated yields (entry 8). Increasing the amount of $\mathrm{Br}_{2}$ (to $5 \mathrm{~mol} \%$ ) in the catalyst system will improve the reaction rate - the oxidation of 4-(methylthio)benzoic acid could be completed within 5 h (entry 9). Simple alkyl sulfides such as dibutyl sulfide were also efficiently oxidized (entry 11). It is noteworthy 
that function selective oxidation can be achieved with this method, which is generally problematic in classical oxidation processes. Under the modified conditions $\left(\mathrm{Br}_{2}, 5 \mathrm{~mol} \%\right)$, the conversion of 4 (methylthio)phenol (entry 10) is only about $25 \%$ within $5 \mathrm{~h}$. Recognizing the oxidation of 4(methylthio)phenol by molecular oxygen to the corresponding 4-(methylsulfoxyl)phenol, an intermediate may be via conjugate transformation converted into a similar-benzoquinone compound, then the ultimate compound is obtained by conjugate match once more. The key of the reaction is the form of the intermediate, the more difficult the intermediate formed, the lower conversion the product received (Scheme 2) [38].

Scheme 2. The catalytic oxidation of 4-(methylthio)phenol.<smiles>CSc1ccc(O)cc1Br</smiles>

\subsection{Mechanism of aerobic sulfide oxidation}

A possible overall mechanism of this new and transition-metal-free catalytic oxidation can be described by the dual cycle in Scheme 3. Thus, transformation of sulfides into their corresponding sulfoxides is fulfilled by the coupling of multiple redox reactions. Initially the electrophilic attack of $\mathrm{Br}_{2}$ on sulfur in the organic phase leads to the sulfoxide [38]. The running of Cycle 1 continuously produces the reoxidation of $\mathrm{HBr}$ to $\mathrm{Br}_{2}$ by $\mathrm{NO}_{2}$ [39], which is the key for a catalytic amount of $\mathrm{Br}_{2}$ to benefit the oxidations of active sulfide substrates. $\mathrm{NO}_{2}$ is reduced to $\mathrm{NO}$ when it completes the oxidation of $\mathrm{HBr}$. $\mathrm{NO}$ is easily released from $\mathrm{NaNO}_{2}$ as an efficient $\mathrm{NO}$ equivalent .The oxidation of $\mathrm{NO}$ into $\mathrm{NO}_{2}$ is a process easily accomplished with molecular oxygen (Cycle 2), and the coupling of the two cycles furnishes a novel, coherent, and efficient aerobic sulfide oxidation system.

Scheme 3. Overall Catalytic Mechanism.

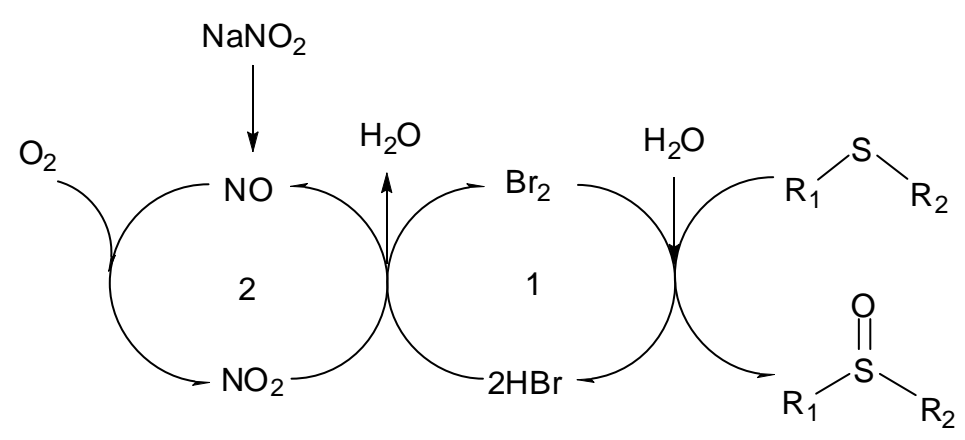

\section{Experimental}

\subsection{Materials}

All methyl aryl sulfides (Wuling Science and Technology\&Industry Co. Ltd.) and their analogues (Zhejiang Shou \& Fu Chemical Co. Ltd), dibutyl sulfide (Shandong Teng \& Wu Spice Co.Ltd), was a 
commercial product used as received without any further purification. Deionised water was used in all experiments. All other solvents used were analytical grade.

\subsection{Instrumentation}

IR spectra were recorded on a Nicolet 20DXB FT-IR instrument. ${ }^{1} \mathrm{H}-\mathrm{NMR}$ spectra were recorded on a Varian Inova 400MHz spectrometer. HPLC chromatograms were recorded with an Agilent 1100 system. GC chromatogram was recorded on a Varian 3700 apparatus. MS spectra was recorded on a HP 6890/5973 instrument.

\subsection{General procedure for catalytic aerobic sulfides oxidation}

Oxidation of methyl phenyl sulfide is described as a representative example of aromatic compounds: in a $100 \mathrm{~mL}$ Schlenk flask equipped with a mechanical stirrer were placed methyl phenyl sulfide $(10 \mathrm{mmol})$, acetonitrile $(20 \mathrm{~mL})$, water $(1.5 \mathrm{~mL}), \mathrm{Br}_{2}(3 \mathrm{~mol} \%)$ and sodium nitrite $(5 \mathrm{~mol} \%)$. The reaction mixture was stirred at $25{ }^{\circ} \mathrm{C}$ under a continuous stream of oxygen $(80 \mathrm{~mL} / \mathrm{min})$. Upon completion after 1 hour, as detected by GC, the solvent was removed and the residue extracted with ethyl acetate. The organic extract was first washed with 5\% sodium bicarbonate solution, then the organic layer was finally dried over anhydrous sodium sulfate. The yield was calculated on the basis of $10 \mathrm{mmol}$ of substrate. The ${ }^{1} \mathrm{H}-\mathrm{NMR}$ spectrum was recorded directly using the isolated product.

\subsection{Spectroscopic data for products}

Methyl phenyl sulfoxide (Table 2, entry 1): Yellow liquid; ${ }^{1} \mathrm{H}-\mathrm{NMR}$ (DMSO-d6): $\delta 2.73\left(3 \mathrm{H}, \mathrm{s}, \mathrm{CH}_{3}\right)$, 7.52-7.59 (3H, m, Ph), 7.67-7.71(2H, m, Ph); IR (KBr, cm $\left.{ }^{-1}\right): v 1048,749,692 ; \mathrm{MS}(\mathrm{EI}), \mathrm{m} / z: 140$ [M] $]^{+}$

4-Methoxyphenyl methyl sulfoxide (Table 2, entry 2): Yellow solid; ${ }^{1} \mathrm{H}-\mathrm{NMR}$ (DMSO-d6): $\delta 2.71(3 \mathrm{H}$, s, $\left.\mathrm{SOCH}_{3}\right), 3.83\left(3 \mathrm{H}, \mathrm{s}, \mathrm{OCH}_{3}\right), 7.13(2 \mathrm{H}, \mathrm{d}, J=8.8 \mathrm{~Hz}, \mathrm{Ph}), 7.63(2 \mathrm{H}, \mathrm{d}, J=8.8 \mathrm{~Hz}, \mathrm{Ph})$; IR $(\mathrm{KBr}$, $\left.\mathrm{cm}^{-1}\right): v 1027,831$; MS (EI), $m / z: 170[\mathrm{M}]^{+}$.

2-Methoxyphenyl methyl sulfoxide (Table 2, entry 3): Yellow liquid; ${ }^{1} \mathrm{H}-\mathrm{NMR}$ (DMSO-d6): $\delta 2.70$ $\left(3 \mathrm{H}, \mathrm{s}, \mathrm{SOCH}_{3}\right), 3.86\left(3 \mathrm{H}, \mathrm{s}, \mathrm{OCH}_{3}\right), 7.14(1 \mathrm{H}, \mathrm{d}, J=7.6 \mathrm{~Hz}, \mathrm{Ph}), 7.21(1 \mathrm{H}, \mathrm{t}, J=7.6 \mathrm{~Hz}, J=7.4 \mathrm{~Hz}$, $\mathrm{Ph}), 7.52(1 \mathrm{H}, \mathrm{t}, J=7.4 \mathrm{~Hz}, J=8.3 \mathrm{~Hz}, \mathrm{Ph}), 7.63(1 \mathrm{H}, \mathrm{d}, J=8.3 \mathrm{~Hz}, \mathrm{Ph}) ; \mathrm{IR}\left(\mathrm{KBr}, \mathrm{cm}^{-1}\right): v 1038,757$; MS (EI), $m / z: 170[\mathrm{M}]^{+}$.

4-Methylphenyl methyl sulfoxide (Table 2, entry 4): Yellow solid; ${ }^{1} \mathrm{H}-\mathrm{NMR}$ (DMSO-d6): $\delta 2.35$ ((3H, s, $\left.\mathrm{CH}_{3}\right), 2.69\left(3 \mathrm{H}, \mathrm{s}, \mathrm{SOCH}_{3}\right), 7.4(2 \mathrm{H}, \mathrm{d}, J=8.4 \mathrm{~Hz}, \mathrm{Ph}), 7.56(2 \mathrm{H}, \mathrm{d}, J=8.4 \mathrm{~Hz}, \mathrm{Ph}) ; \mathrm{IR}\left(\mathrm{KBr}, \mathrm{cm}^{-1}\right)$ : $v$ 1046, 810; MS (EI), m/z: $154[\mathrm{M}]^{+}$.

4-Fluorophenyl methyl sulfoxide (Table 2, entry 5): Yellow solid; ${ }^{1} \mathrm{H}-\mathrm{NMR}$ (DMSO-d6): $\delta 2.73$ (3H, s, $\left.\mathrm{CH}_{3}\right), 7.40(2 \mathrm{H}, \mathrm{t}, J=9.0 \mathrm{~Hz}, J=8.8 \mathrm{~Hz}, \mathrm{Ph}), 7.74(2 \mathrm{H}, \mathrm{q}, J=8.8 \mathrm{~Hz}, J=5.4 \mathrm{~Hz}, \mathrm{Ph}) ; \mathrm{IR}\left(\mathrm{KBr}, \mathrm{cm}^{-1}\right)$ : $v 1048,834$; MS (EI), $m / z: 158[\mathrm{M}]^{+}$.

2-Chlorophenyl methyl sulfoxide (Table 2, entry 6): Yellow liquid; ${ }^{1} \mathrm{H}-\mathrm{NMR}$ (DMSO-d6): $\delta 2.81(3 \mathrm{H}$, 
$\left.\mathrm{s}, \mathrm{CH}_{3}\right), 7.56-7.59(\mathrm{~m}, 2 \mathrm{H}), 7.62 \sim 7.68(\mathrm{~m}, 1 \mathrm{H}), 7.81-7.86(\mathrm{~m}, 1 \mathrm{H})$; IR $\left(\mathrm{KBr}, \mathrm{cm}^{-1}\right): v 1067,759$; MS (EI), $m / z: 174[\mathrm{M}]^{+}$.

1-(4-Methansulfinylphenyl)-ethanone (Table 2, entry 7): Yellow solid; ${ }^{1} \mathrm{H}-\mathrm{NMR}$ (DMSO-d6): $\delta 2.63$ $\left(3 \mathrm{H}, \mathrm{s}, \mathrm{COCH}_{3}\right), 2.80\left(3 \mathrm{H}, \mathrm{s}, \mathrm{SOCH}_{3}\right), 7.83(2 \mathrm{H}, \mathrm{d}, J=8.4 \mathrm{~Hz}, \mathrm{Ph}), 8.13(2 \mathrm{H}, \mathrm{d}, J=8.4 \mathrm{~Hz}, \mathrm{Ph})$; IR $\left(\mathrm{KBr}, \mathrm{cm}^{-1}\right): v 1674,1047,830$; MS (EI), $\mathrm{m} / z: 182[\mathrm{M}]^{+}$.

4-Chlorophenyl methyl sulfoxide (Table 2, entry 8): Yellow solid; ${ }^{1} \mathrm{H}-\mathrm{NMR}$ (DMSO-d6): $\delta 2.78$ (3H, s, $\left.\mathrm{CH}_{3}\right), 7.67(2 \mathrm{H}, \mathrm{d}, J=8.4 \mathrm{~Hz}, \mathrm{Ph}), 7.73(2 \mathrm{H}, \mathrm{d}, J=8.4 \mathrm{~Hz}, \mathrm{Ph})$; IR (KBr, cm $\left.{ }^{-1}\right): v 1051,822$; MS (EI), $m / z: 174[\mathrm{M}]^{+}$.

4-Methanesulfinylbenzoic acid (Table 2, entry 9): White powder; ${ }^{1} \mathrm{H}-\mathrm{NMR}$ (DMSO-d6): $\delta 2.79$ (3H, s, $\left.\mathrm{CH}_{3}\right), 7.81(2 \mathrm{H}, \mathrm{d}, J=8.0 \mathrm{~Hz}, \mathrm{Ph}), 8.11(2 \mathrm{H}, \mathrm{d}, J=8.0 \mathrm{~Hz}, \mathrm{Ph}), 13.30(1 \mathrm{H}, \mathrm{s}, \mathrm{COOH}) ; \mathrm{IR}\left(\mathrm{KBr}, \mathrm{cm}^{-1}\right)$ : $v 2773,1690,1083,856$; MS (EI), $m / z: 184[\mathrm{M}]^{+}$.

Dibutyl sulfoxide (Table 2, entry 11): Yellow liquid; ${ }^{1} \mathrm{H}-\mathrm{NMR}$ (DMSO-d6): $\delta 0.91\left(3 \mathrm{H}, \mathrm{t}, \mathrm{CH}_{3}\right), 1.41$ $\left(2 \mathrm{H}, \mathrm{m}, \mathrm{CH}_{2}\right), 1.608\left(2 \mathrm{H}, \mathrm{m}, \mathrm{CH}_{2}\right), 2.657\left(2 \mathrm{H}, \mathrm{m}, \mathrm{SOCH}_{2}\right)$; IR $\left(\mathrm{KBr}, \mathrm{cm}^{-1}\right): v 737,923,1021,1085$; MS (EI), $m z: 162[\mathrm{M}]^{+}$.

\section{Conclusions}

In conclusion, we have successfully developed a highly efficient, transition-metal-free catalytic process for the aerobic oxidation of sulfides with molecular oxygen. It should be noted that the quantitative oxidation of methyl phenyl sulfide to the corresponding sulfoxides with excellent yields can be achieved without acid under mild conditions. A catalyst system is based on molecular bromine as an active catalyst in the presence of very inexpensive $\mathrm{NaNO}_{2}$ as co-catalysts. The results showed that reaction with a low concentration of $\mathrm{Br}_{2}$ and $\mathrm{NaNO}_{2}$ in a small amount of water is highly selective to the desired products without over-oxidation. This reliable non-metal catalytic system for aerobic sulfide oxidation is applicable to a wide range of sulfides, including methyl aryl sulfides and their analogues.

\section{Acknowledgements}

The research was supported by Program for Changjiang Scholars and Innovative Research Team in University ( IRT0711) .

\section{References and Notes}

1. Hudlicky, M. Oxidations in Organic Chemistry; American Chemical Society: Washington, DC, USA, 1990.

2. Carreno, M.C. Applications of Sulfoxides to asymmetric synthesis of biologically active compounds. Chem. Rev. 1995, 95, 1717-1760.

3. Solladie, G. Comprehensive Organic Synthesis; Trost, B.M., Fleming, I., Eds.; Pergamon: Oxford, 
UK, 1991; Volume 6, pp.148-170.

4. Holland, H.L. Chiral sulfoxidation by biotransformation of organic sulfides. Chem. Rev. 1988, 88, 473-485.

5. Block, E. The organosulfur chemistry of the genus allium-implications for the organic chemistry of sulfur. Angew. Chem. Int. Ed. Engl. 1992, 31, 1135-1178.

6. Compagnini, A.; Santagati, M.; Marziano, N.; Passerini, R. Reaction of nitric acid with aromatic sulfur compounds. VI. Scission of diphenyl sulfides with bromine and nitric acid. Ann. ChimRome 1970, 60, 537-542.

7. Oae, S.; Kawai, T.; Furukawa, N. Ligand coupling through $\sigma$-sulfurane-complete retention of configuration of 1-phenylethyl group in the reaction of 1-phenylethyl 2-pyridyl sulfoxide with grignard reagent1. Tetrahedron Lett. 1984, 35, 69-72.

8. Xiong, Z.X.; Huang, N.P.; Zhong, P. A selective and convenient oxidation of sulfides to sulfoxides with trichloroisocyanuric acid. Syn.Commun. 2001, 31, 245-248.

9. Novitskaya, N.N.; Chernikova, S.I. Comparative study of the oxidation of sulfides by hydrogen peroxide. Neftekhimiya 1970, 10, 429-436.

10. Kirihara, M.; Yamamoto, J.; Noguchi T.; Hirai, Y. Selective synthesis of sulfoxides and sulfones by tantalum (V) catalyzed oxidation of sulfides with $30 \%$ hydrogen peroxide. Tetrahedron Lett. 2009, 50, 1180-1183.

11. Boring, E.; Geletii, Y.V.; Hill, C.L. Catalysts for Selective Aerobic Oxidation under Ambient Conditions, in Catalysis by Metal Complexes; Simándi, L.I., Ed.; Springer: New York, NY, USA, 2003; Volume 26, pp. 227-264.

12. Ishii, Y.; Sakaguchi, S. Modern Oxidation Methods; Wiley-VCH: Weinheim, Gemany, 2004; pp. 119-163.

13. Bortolini, O.; Di Furia, F.; Modena, G. Metal catalysis in oxidation by peroxides. Part 16. Kinetics and mechanism of titanium-catalyzed oxidation of sulfides with hydrogen peroxide. $J$. Mol. Catal.1982, 16, 69-80.

14. Linden, A.A.; Kruger, L.; Backvall, J.E. Highly Selective sulfoxidation of allylic and vinylic sulfides by hydrogen peroxide using a flavin as catalyst. J. Org. Chem. 2003, 68, 5890-5896.

15. Yao, H.; Richardson D.E. Bicarbonate surfoxidants: Micellar oxidations of aryl sulfides with bicarbonate-activated hydrogen peroxide. J. Am. Chem. Soc. 2003, 125, 6211-6221.

16. Trevisan, V.; Signoretto, M.; Colonna, S.; Pironti, V.; Strukul, G. Microencapsulated chloroperoxidase as a recyclable catalyst for the enantioselective oxidation of sulfides with hydrogen peroxide. Angew. Chem. Int. Ed. 2004, 43, 4097-4099.

17. Mba, M.; Prins L.J.; Licini, G. C3-Symmetric Ti(IV) triphenolate amino complexes as sulfoxidation catalysts with aqueous hydrogen peroxide. Org. Lett. 2007, 9, 21-24.

18. Golchoubian, H.; Hosseinpoor, F. Effective oxidation of sulfides to sulfoxides with hydrogen peroxide under transition-metal-free conditions. Molecules 2007, 12, 304-311.

19. Mashkina, A.V. Catalytic synthesis of sulfoxides and sulfones via oxidation of sulfides by molecular oxygen. Cat. Rev. Sci. Eng. 1990, 32, 105-161.

20. Komatsu, M.; Uda, M.; Suzuki, H. Air oxidation of sulfides to sulfoxides using $\mathrm{BiBr}_{3}-\mathrm{Bi}\left(\mathrm{NO}_{3}\right)_{3}$ as a binary catalyst. Chem. Lett. 1997, 1229-1230.

21. Iwahama, T.; Sakaguchi, S.; Ishii, Y. Selective oxidation of sulfides to sulfoxides with molecular 
oxygen catalyzed by $N$-hydroxyphthalimide (NHPI) in the presence of alcohols. Tetrahedron lett. 1998, 39, 9059-9062.

22. Shii, Y.; Sakaguchi, S.; Iwahama, T. Innovation of hydrocarbon oxidation with molecular oxygen and related reactions. Adv. Synth. Catal. 2001, 343, 393-427.

23. Huang, R.L.; Espenson, J.H. Molecular oxygen reactions catalyzed by an oxorhenium(V) Compound. J. Mol. Catal. A Chem. 2001, 168, 39-46.

24. Aldea, R.; Alper, H. Selective aerobic oxidation of sulfides using a novel palladium complex as the catalyst precursor. J.Org. Chem. 1995, 60, 8365-8366.

25. Zhou, X.T.; Ji, H.B.; Cheng, Z.; Xu, J.C.; Pei, L.X.; Wang, L.F. Selective oxidation of sulfides to sulfoxides catalyzed by ruthenium (III) meso-tetraphenylporphyrin chloride in the presence of molecular oxygen. Bioorg. Med. Chem. Lett. 2007, 17, 4650-4653.

26. Song, G.Q.; Wang, F.; Zhang, H.; Lu, X.L.; Wang, C. Efficient oxidation of sulfides catalyzed by transition metal salts with molecular oxygen in the presence of aldehydes. Syn. Commun. 1998, 28, 2783-2787.

27. Firouzabadi, H.; Iranpour, N.; Zolfigol, M.A. Selective and effcient transformation of thioethers to their sulfoxides and catalytic conversion of thiols to the disulfides with hydrate iron(III) and copper(II) nitrates in aprotic organic solvents or under solvent free conditions. Syn. Commun. 1998, 28, 1179-1187.

28. Martin, S.E.; Rossi, L.I. An efficient and selective aerobic oxidation of sulfides to sulfoxides catalyzed by Fe(NO3)3-FeBr3. Tetrahedron Lett. 2001, 42, 7147-7151.

29. Okun, N.M.; Tarr, J.C.; Hilleshiem, D.A.; Zhang, L.; Hardcastle, K.I.; Hill, C.L. Highly reactive catalysts for aerobic thioether oxidation. The Fe-substituted polyoxometalate/hydrogen dinitrate system. J. Mol. Catal. A Chem. 2006, 246, 11-17.

30. Dell'Anna, M.M.; Mastrorilli, P.; Nobile, C.F. Aerobic oxidation of sulfides catalyzed by cobalt(II) complexes under homogeneous and heterogeneous conditions. J. Mol. Catal. A Chem. 1996, 108, $57-62$.

31. Boring, E; Geletii, Y.V; Hill, C.L. A homogeneous catalyst for selective $\mathrm{O}(2)$ oxidation at ambient temperature diversity-based discovery and mechanistic investigation of thioether oxidation by the $\mathrm{Au}(\mathrm{III}) \mathrm{Cl}(2) \mathrm{NO}(3)$ (thioether) $/ \mathrm{O}(2)$ system. J. Am. Chem. Soc. 2001, 123, $1625-1635$.

32. Bosch, E, Kochi, J.K. Selective catalysis of thioether oxidations with dioxygen. Critical role of nitrosonium EDA Complexes in the thermal and photochemical transfer of oxygen atom from nitrogen oxides to sulfur centers. J. Org. Chem. 1995, 60, 3172-3183.

33. Stamier, J.S.; Singel, D.J.; Loscalzo, J. Biochemistry of nitric oxide and its redox-activated forms. Science 1992, 258, 1898-1902.

34. Wang, P.G.; Xian, M.; Tang, X.; Wu, X.; Wen, Z.; Cai, T.; Janczuk, A.J. Nitric oxide donors: Chemical activities and biological applications. Chem. Rev. 2002, 102, 1091-1134.

35. Zhang, H.; Chen, C.Y.; Liu, R.H.; Rui, Y. DBDMH/ $/ \mathrm{NaNO}_{2}$ catalyst: Transition-metal-free approach to highly efficient aerobic oxidation of sulfides to sulfoxides. Syn. Commun. 2008, 38, 4445-4451.

36. Chen, C.Y.; Zhang, H.; Zhang, L.X.; Li, L.D.; Yan, Y.L. HBr/t-BuONO catalysts for activation of oxygen to selective aerobic sulfide oxidation. Chin. J. Org. Chem. 2008, 28, 1978-1981. 
37. Kowalski, P.; Mitka, K.; Ossowska, K.; Kolarska, Z. Oxidation of sulfides to sulfoxides. Part 1: Oxidation using halogen derivatives. Tetrahedron 2005, 61, 1933-1953.

38. Bravo, A.; Dordi, B.; Fontana, F.; Minisci, F. Oxidation of organic Sulfides by $\mathrm{Br}_{2}$ and $\mathrm{H}_{2} \mathrm{O}_{2}$ electrophilic and free-radical processes. J. Org. Chem. 2001, 66, 3232-3234.

39. Liu, R.H.; Liang, X.M.; Dong, C.Y.; Hu, X.Q. Transition-metal-free: A highly efficient catalytic aerobic alcohol oxidation process. J. Am. Chem. Soc. 2004, 126, 4112-4113.

Sample Availability: Samples of the compounds are available from the authors.

(C) 2010 by the authors; licensee Molecular Diversity Preservation International, Basel, Switzerland. This article is an open-access article distributed under the terms and conditions of the Creative Commons Attribution license (http://creativecommons.org/licenses/by/3.0/). 